\title{
Retrospective karyotype study in mentally retarded patients
}

\author{
Wellcy Gonçalves Teixeira ${ }^{1}$, Fabiana Kalina Marques ${ }^{2 *}$, Maíra Cristina Menezes Freire ${ }^{3}$ \\ ${ }^{1} \mathrm{MSc}$ in General and Applied Biology - Laboratory Specialist at Instituto Hermes Pardini, Belo Horizonte, MG, Brazil \\ ${ }^{2} \mathrm{MSc}$ in Genetics - Researcher at Instituto Hermes Pardini, Belo Horizonte, MG, Brazil \\ ${ }^{3} \mathrm{PhD}$ in Genetics - Researcher at Instituto Hermes Pardini, Belo Horizonte, MG, Brazi
}

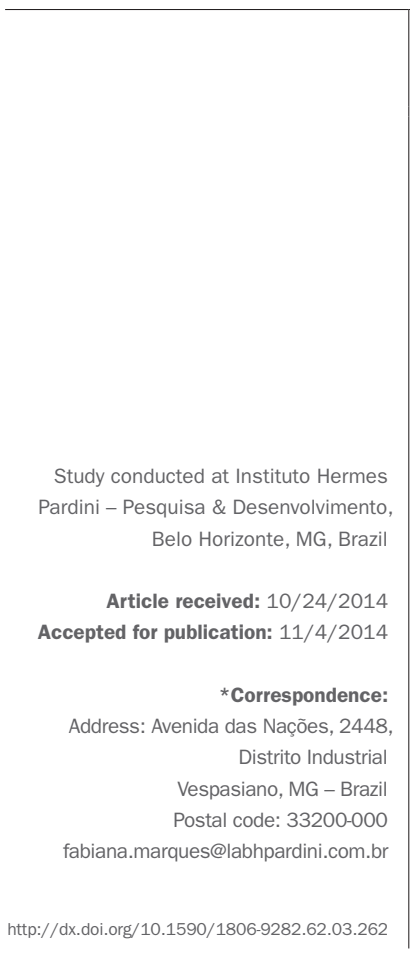

\section{SUMMARY}

Objective: To describe the chromosomal alterations in patients with mental retardation (MR) using G-banding karyotype analysis.

Method: A retrospective study of the results G-banding karyotype analysis of 369 patients investigated for MR was performed. Based on the structural rearrangements found, the authors searched all chromosomal regions related with breakpoints, and these were compared with the literature on MR and databases.

Results: 338 (91.6\%) normal cases, and 31 (8.4\%) with some type of chromosomal abnormality were identified. Among the altered cases, 21 patients (67.8\%) were identified with structural chromosomal alterations, nine (29\%) with numerical alterations, and one (3.2\%) with numerical and structural alterations.

Conclusion: Structural chromosomal abnormalities were observed more frequently in this study. G-banding karyotyping contributes to the investigation of the causes of MR, showing that this technique can be useful for initial screening of patients. However, higher resolution techniques such as array based comparative genomic hybridization $(\mathrm{aCGH})$ and multiplex ligation-dependent probe amplification (MPLA) can detect submicroscopic alterations commonly associated with MR.

Keywords: karyotype, intellectual disability, chromosome aberrations.

\section{INTRODUCTION}

According to the definition of classical cytogenetics, the term aneuploidy corresponds to changes in number of chromosomes, including the presence of an extra copy of a particular chromosome (trisomy) or the absence of one chromosome (monosomy) leading to abnormal karyotype. However, with the advent of new high-resolution molecular technologies, new aneuploidy syndromes have been identified, including deletions and duplications of chromosomal regions. ${ }^{1}$ Changes in gene dosage resulting from such deletions and duplications are commonly related to cases of mental retardation. It is estimated that over $15 \%$ of cases of severe mental retardation are due to microscopic cytogenetic abnormalities. ${ }^{2}$

Mental retardation (MR), ethically accepted as intellectual retardation or cognitive delay, is characterized by significant limitations in intellectual functions and adaptive behavior of an individual, with onset of symptoms before the age of 18 years. Adaptive behavior refers to adaptive conceptual, social and practical skills, while intellectual functions are often measured using intelligence test instruments that generate an intelligence quotient (IQ)., ${ }^{2,3}$
In some cases, MR can be categorized as syndromic, i.e. the child has associated dysmorphic features identifying a genetic syndrome. However, intellectual disability is extremely heterogeneous, a consequence of the large number of different syndromes related to MR, which renders accurate diagnosis impossible based only on the clinical picture. ${ }^{4}$ Accurate diagnosis is essential to provide a specific treatment, to establish a clinical predictor of quality of life, to educate parents on the characteristics and progression of the syndrome, and finally, to define a reproductive prognosis for the family.

Many cases of MR resulting from duplication and recurrent deletions were initially identified by conventional microscopy techniques or banding. G-banding karyotype analysis is a technique used to identify individual human chromosomes in many laboratories. This technique, also known as GTG (G-bands by trypsin using Giemsa), is based on chromosomes digestion with proteolytic enzymes, which are then stained with Giemsa. After staining, each pair of chromosomes exhibits a characteristic pattern of light and dark bands ( $G$ bands), which can be individually differentiated under a microscope. 
Knowing the importance of accurate diagnosis of MR, and being aware of the extensive clinical use of G-banding as an important method of diagnosis, this study aimed to carry out a retrospective analysis of all the results of G-banding karyotyping of patients with MR, performed in 2009 at Instituto Hermes Pardini, Sector of Human Cytogenetics, in Belo Horizonte, Minas Gerais, Brazil.

\section{Method}

The present study followed the guidelines of the Brazilian National Health Council - CNS Resolution 196/96, and the identity of all patients was kept confidential. Chromosome study was conducted at the Laboratory of Cytogenetics of Instituto Hermes Pardini using G-banding karyotype analysis.

For each patient, peripheral blood was collected in heparin and from these samples cell cultures were prepared. The cell cultures were treated with colchicine and subjected to hypotonic shock. Then, they were fixed on slides for subsequent staining of G-bands with trypsin and Giemsa.

Slides evaluation was performed using a microscope $\left(\mathrm{NIKON}^{\circledR}\right.$, model E 400$)$ coupled to the karyotype analysis software (Applied Spectral Imaging ${ }^{\circledR}$, version 6.0). Karyotypes were described according to the standards present in the 2013 International System for Human Cytogenetic Nomenclature (ISCN). ${ }^{5}$

A survey of karyotyping results was carried out, including types of rearrangements, chromosomal region, the possible genes involved, and MR syndromes associated. Based on the structural rearrangements found, we searched all chromosomal regions related with breakpoints, which were then compared with the literature on MR. For this comparison, renowned databases available for public consultation on the international computer network were used, such as the Mapviewer-National Center for Biotechonology Information. ${ }^{72}$ Then, all the specific chromosomal regions were researched in the scientific literature as to their association with MR.

\section{RESULTS}

During 2009, we evaluated the karyotyping results of 369 patients with MR, of which 143 (38.8\%) were female, and $226(61.2 \%)$ were male. For most of the patients, 338 (91.6\%), karyotypes were compatible with normality, while $31(8.4 \%)$ cases had some type of chromosomal abnormality. Of this total of 31 altered cases, 21 patients (67.8\%) were identified with structural alterations, 9 (29\%) with numerical abnormalities, and $1(3.2 \%)$ with numerical and structural alterations (Figure 1).

Among the patients with identified numerical chromosomal abnormalities, five cases had aneuploidy of sex chromosomes: four cases of 47,XXY karyotype, and one case of $\mathrm{X}$ monosomy (45, $\mathrm{X}$ karyotype). Regarding autosomal chromosomes, three cases of free trisomy 21 $(47, \mathrm{XX},+21$ karyotype) were detected. The case of numerical and structural alteration corresponded to a 47,XXY,dup(18)(p12.2 p12.3) karyotype.

As for structural chromosomal abnormalities, reciprocal translocations, inversions, deletions, additional chromosomal segments, and insertions were observed. Based on the comparison of results of karyotypes with structural alterations and their specific chromosomal regions, we were able to identify breakpoints involving $1 \mathrm{p} 22.3 ; 2 \mathrm{p} 24$; 2q22; 3p13; 3q26.2; 3q12; 5p15.1; 5p15.2; 5p15.3; 6q25.3; 7p14; 8p23.1; 8q11.2; 9p24; 10q26.3; 11q23.3; 11q21; 12q24.31; 15q25; 15q26; 17p11.2; 17q21; 18p11.1; 18p11.32; $20 \mathrm{q} 11.2 ; 22 \mathrm{q} 13$. The respective rearrangements as well as

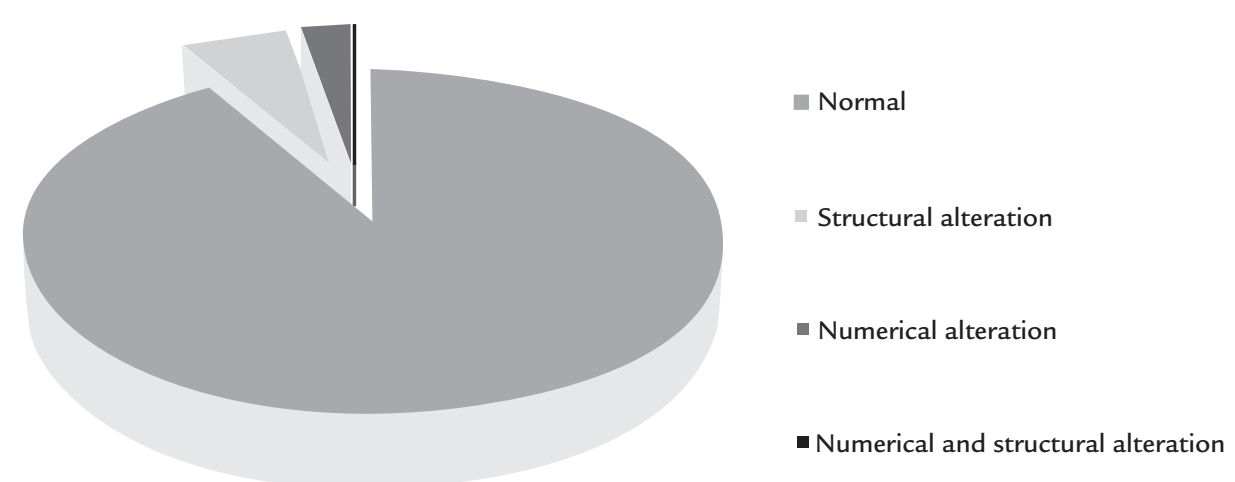

FIGURE 1 Distribution of results of 369 patients who underwent G-banding karyotyping for investigation of mental retardation in 2009 at Instituto Hermes Pardini. 
the correlation between the genes involved and syndromes related with MR are shown in Table 1. With the exception of the deletion on the short arm of chromosome 5 [46,XX,del(5)(p11.2) karyotype], found in three cases, all other changes occurred once in this study.

Considering the structural alterations, three cases revealed additional marker chromosomes of unknown origin, two of which were mosaic marker chromosomes. The cases of mosaic presented 47,XX,+mar[13]/46,XX[17] karyotype (mosaicism for one lineage with presence of an additional marker chromosome, and another lineage with normal complement) and 47,XY, $+\mathrm{r}[8] / 46, \mathrm{XY}[22]$ karyotype (mosaicism for one lineage with an additional marker chromosome ring, and another lineage with normal complement). In one case, the additional marker chromosome was seen in all cells analyzed $(47, \mathrm{XX},+$ mar $)$.

\section{Discussion}

This study presents a retrospective analysis of the results of G-banding karyotyping of individuals with MR assessed at Instituto Hermes Pardini in 2009, and the comparison of these results with literature data. Based on this evaluation, we were able to identify chromosomal alterations in $8.4 \%$ of patients only. Although this method is important either to explain or rule out causes of $\mathrm{MR}$, it has limitations, especially in relation to the identification of submicroscopic alterations. Thus, other techniques such as fluorescent in situ hybridization (FISH), ${ }^{6}$ comparative genomic hybridization (CGH), array based comparative genomic hybridization $(\mathrm{aCGH}){ }^{7}$ and multiplex ligation-dependent probe amplification (MLPA), ${ }^{8}$ are more suitable to detect submicroscopic rearrangements responsible for most cases of MR, especially in cases of idiopathic MR.

Among the numerical chromosomal abnormalities identified in this study, the 47,XXY karyotype was most frequent. This abnormality causes Klinefelter syndrome, the most common numerical chromosomal disorder among men. The estimated frequency of this disorder is between 1:500 and 1:1,000 live births. Men with Klinefelter syndrome usually have delayed auditory processing, language dysfunction and, in rare cases, severe intellectual retardation. ${ }^{2}$

Turner syndrome is less common than other sex chromosome aneuploidies, and its most important chromosome constitution is $45, \mathrm{X}$, found in one case in this study. Some patients, in addition to the unique physical characteristics of this syndrome, have a non-verbal IQ significantly lower than their verbal IQ; many require educational intervention, especially in mathematics. ${ }^{9,10}$
The only numerical alteration of autosomal chromosome found in this study was trisomy $21(47, \mathrm{XX},+21)$. This chromosome constitution is observed in patients with Down syndrome, an example of neurogenetic disorder related to aneuploidy, ${ }^{1}$ and corresponds to the most common genetic cause of moderate mental retardation ${ }^{11,12}$ and intellectual disability. ${ }^{13}$

In this study we also identified three cases of additional marker chromosomes, two with mosaic karyotype $(47, \mathrm{XX},+\operatorname{mar}[13] / 46, \mathrm{XX}[17]$ and $47, \mathrm{XY},+\mathrm{r}[8] / 46, \mathrm{XY}[22])$. Supernumerary marker chromosomes are a heterogeneous group of structurally abnormal chromosomes derived from any of the 24 chromosomes, but they cannot be identified using conventional cytogenetic techniques. ${ }^{14}$ They are found in clinically normal individuals, but are often reported in patients with mental retardation and infertility. ${ }^{15}$ Mosaicism associated with marker chromosomes is a well-known finding, observed in approximately $50 \%$ of cases. Different types of mosaicism can be found, the most common being $47, \mathrm{XX},+$ mar $/ 46, \mathrm{XX} .{ }^{14}$

The analysis of chromosomal abnormalities and comparison with literature data revealed that the alterations identified in this study occur in regions determined by breakpoints also described in previous studies with patients with MR. In the 46,XX,inv(2)(p24q22) inversion, for example, there is the q22 breakpoint located close to the ZEB2 gene. Deletions involving this gene are responsible for Mowat-Wilson syndrome, and MR is one of its main clinical manifestations. ${ }^{16}$ The $6 \mathrm{q} 25.3$ point of $46, \mathrm{XX}, \mathrm{t}(6 ; 11)(\mathrm{q} 25.3 ; \mathrm{q} 21)$ translocation is associated with a deletion syndrome with moderate MR. ${ }^{17}$

The present study found three patients with terminal deletion in the short arm of chromosome 5 and p15.2 breakpoint [46,XX,del(5)(p15.2)]. Most deletions in the short arm of chromosome 5 are related to Cri-du-Chat syndrome, which is a genetic disease caused by deletion of variable size, with breakpoints ranging from $\mathrm{p} 13$ to p15.2. ${ }^{18}$ A distinctive cry (similar to that of a meowing kitten), dysmorphisms, psychomotor delay, and MR are some of the clinical manifestations of the syndrome. Studies confirm the critical region of the syndrome, mapped in $5 \mathrm{p} 15$, with genes related to Cri-du-Chat in $\mathrm{p} 15.3$, and dysmorphisms and MR in p15.2. ${ }^{18,19}$

With the aid of websites GenScript ${ }^{73}$ and ClinVar, ${ }^{74}$ we were able to identify genes within the chromosome regions involved with the identified structural alterations, and evaluate which of them have already been reported in relation with MR. We found reports on all of the regions identified in our study as containing genes that due to loss or gain in the number of copies resulted in devel- 
TABLE 1 List of breakpoints found in the detected structural alterations and comparison with literature data on mental retardation.

\begin{tabular}{|c|c|c|c|c|c|c|}
\hline Karyotype & $\begin{array}{l}\mathrm{N}^{\circ} \text { of } \\
\text { cases }\end{array}$ & $\begin{array}{l}\text { Chromosomal } \\
\text { region }\end{array}$ & Rearrangement & Gene involved & MR syndrome & Reference \\
\hline \multirow{5}{*}{$\begin{array}{l}46, \mathrm{XY}, \mathrm{t}(1 ; 11) \\
(\mathrm{p} 22.3 ; \mathrm{q} 23.3)\end{array}$} & \multirow[t]{5}{*}{1} & \multirow[t]{3}{*}{$1 \mathrm{p} 22$} & \multirow{3}{*}{$\begin{array}{l}\text { Duplication; } \\
\text { deletion }\end{array}$} & \multirow[t]{3}{*}{-} & \multirow{2}{*}{$\begin{array}{l}\text { Kabuki makeup } \\
\text { syndrome }\end{array}$} & Lo et al. $1998 ;^{22}$ \\
\hline & & & & & & Carllier et al. $2008^{23}$ \\
\hline & & & & & Goldenhar syndrome & \\
\hline & & \multirow[t]{2}{*}{ 11q23.3-qter } & \multirow{2}{*}{$\begin{array}{l}\text { Trisomy; deletion; } \\
\text { monosomy }\end{array}$} & \multirow[t]{2}{*}{-} & \multirow[t]{2}{*}{ Dandy Walker variant } & Weimer et al. $2006 ;{ }^{24}$ \\
\hline & & & & & & Ounap et al. $2002^{25}$ \\
\hline \multirow{6}{*}{$\begin{array}{l}46, X X, \operatorname{inv}(2) \\
(p 24 q 22)\end{array}$} & \multirow[t]{6}{*}{1} & 2p24-pter; 2p24; & \multirow{3}{*}{$\begin{array}{l}\text { Trisomy; balanced } \\
\text { translocation }\end{array}$} & \multirow[t]{3}{*}{-} & \multirow[t]{3}{*}{-} & Match et al. 2007; ${ }^{26}$ \\
\hline & & 2p24.2-p25.1; & & & & Talisseti et al. $2003 ;{ }^{27}$ \\
\hline & & 2p24.3-pter & & & & Roggenbuck et al. $2001^{28}$ \\
\hline & & $2 q 22$ & \multirow[t]{3}{*}{ Deletion } & \multirow[t]{3}{*}{ ZEB2 } & \multirow{3}{*}{$\begin{array}{l}\text { Mowat-Wilson } \\
\text { syndrome }\end{array}$} & Balasubramanian et al. \\
\hline & & $2 q 22.2 ; 2 q 22-q 23$ & & & & $2010 ;{ }^{29}$ Ballarati et al. 2009; ${ }^{30}$ \\
\hline & & $2 q 22-q 24.2$ & & & & Saunders et al. $2009^{31}$ \\
\hline \multirow{4}{*}{$\begin{array}{l}46, X Y, \operatorname{inv}(3) \\
(p 13 q 26.2)\end{array}$} & \multirow[t]{4}{*}{1} & 3p13; 3p13-p12 & \multirow[t]{2}{*}{ Inversion } & \multirow[t]{2}{*}{-} & \multirow[t]{2}{*}{ Bardet-Biedl syndrome } & Héron et al. 2005;32 \\
\hline & & & & & & Ghadami et al. $2000^{33}$ \\
\hline & & $3 q 26.2-q 26.31$ & Trisomy & - & Chromosome 3q & Abreu-González et al. \\
\hline & & $3 q 25.1-26.2$ & & & duplication syndrome & $2013 ;{ }^{34}$ Faas et al. $2002^{35}$ \\
\hline \multirow{4}{*}{$\begin{array}{l}46, X X, t(3 ; 8) \\
(q 12 ; q 11.2)\end{array}$} & \multirow[t]{4}{*}{1} & $3 q 12-q 23$ & \multirow{2}{*}{$\begin{array}{l}\text { Duplication; } \\
\text { deletion }\end{array}$} & \multirow[t]{2}{*}{-} & \multirow[t]{2}{*}{-} & Gamerding et al. $2006 ;^{36}$ \\
\hline & & $3 q 12-q 21$ & & & & Okada et al. $1987^{37}$ \\
\hline & & $8 q 11.2$ & Duplication; & CHD7 & Charge syndrome & Amouroux et al. $2012 ;^{38}$ \\
\hline & & $8 q 11.2-q 13$ & deletion & & & Verhoeven et al. $2012^{39}$ \\
\hline $46, \mathrm{XY}, \operatorname{der}(5) \operatorname{del}(5)$ & 1 & $5 p 15.1$ & Trisomy; & - & Cri-du-Chat syndrome & Balaiardo et al. $2003 ;{ }^{40}$ Weeb \\
\hline (?p15.1)add(?p15) & & & duplication & & & et al. $1988^{41}$ \\
\hline $46, X X, \operatorname{del}(5)$ & 3 & $5 p 15.2$ & Translocation and & SRD5A1,POLS & & Harvard et al. $2005 ;{ }^{19} \mathrm{Wu}$ et \\
\hline$(p 15.2)$ & & & deletion & & & al. $2005^{42}$ \\
\hline & & $5 p 15.3$ & Deletion & - & & Moreira et al. $2008 ;{ }^{43}$ \\
\hline & & & & & & Laczmanska et al. $2006^{44}$ \\
\hline $46, X X, t(6 ; 11)$ & 1 & 6q25.3-qter & Deletion & TBP & Chromosome 6q & Abu-Amero et al. $2010 ;{ }^{17}$ \\
\hline$(q 25.3 ; q 21)$ & & & & & deletion syndrome & Lukusa et al. $2001^{45}$ \\
\hline & & $\begin{array}{l}11 q 14.1-q 23.2 \\
11 q 21\end{array}$ & $\begin{array}{l}\text { Deletion; } \\
\text { translocation }\end{array}$ & $F Z D 4$ & $\begin{array}{l}\text { Trichorhinophalangeal } \\
\text { syndrome }\end{array}$ & $\begin{array}{l}\text { Li et al. } 2006 ;{ }^{46} \text { Sanchez et al. } \\
1985^{47}\end{array}$ \\
\hline $\begin{array}{l}46, X X, \operatorname{ins}(7 ; ?) \\
(p 14 ; ?)\end{array}$ & 1 & $\begin{array}{l}\text { 7p14.3; } \\
\text { 7p14-p15; 7p14 }\end{array}$ & Deletion & GLI3 & $\begin{array}{l}\text { Greig } \\
\text { cephalopolysyndactyly } \\
\text { syndrome }\end{array}$ & $\begin{array}{l}\text { Debeer et al. 2007; }{ }^{48} \text { Duno et } \\
\text { al. } 2004^{49}\end{array}$ \\
\hline $\begin{array}{l}46, X Y, \operatorname{del}(8) \\
(p 23.1)\end{array}$ & 1 & $\begin{array}{l}8 p 23.1 ; 8 p 22- \\
8 p 23.1 ; 8 p 23.1- \\
\text { pter }\end{array}$ & $\begin{array}{l}\text { Deletion; } \\
\text { duplication }\end{array}$ & - & Kabuki syndrome & $\begin{array}{l}\text { Wu et al. } 2010 ;^{50} \text { Sanlaville et } \\
\text { al. } 2005 ;{ }^{51} \text { Zafra et al. } 2005^{52}\end{array}$ \\
\hline $46, \mathrm{XY}, \operatorname{add}(9)(\mathrm{p} 24)$ & 1 & $\begin{array}{l}\text { 9p23-pter; } \\
\text { 9p24.2-pter; } \\
\text { 9p24.3 }\end{array}$ & $\begin{array}{l}\text { Deletion; } \\
\text { duplication }\end{array}$ & $D M R T$ & $\begin{array}{l}\text { Chromosome 9p } \\
\text { deletion syndrome }\end{array}$ & $\begin{array}{l}\text { Barbaro et al. } 2009 ;^{53} \\
\text { Yang et al. } 2012^{54}\end{array}$ \\
\hline $46, X X, \operatorname{der}(10)$ & 1 & 10q26-qter & Deletion & - & - & Lam et al. $2006^{55}$ \\
\hline $\mathrm{t}(10 ; ? 15)$ & & $15 q 25.3$ & Trisomy; deletion & - & - & Kim et al. $2009 ; ;^{56}$ \\
\hline$(q 26.3 ; ? q 25)$ & & $\begin{array}{l}15 q 25.2 ; 15 q 25- \\
\text { qter }\end{array}$ & & & & Wagenstaler et al. $2007^{57}$ \\
\hline
\end{tabular}


TABLE 1 (Cont.) List of breakpoints found in the detected structural alterations and comparison with literature data on mental retardation.

\begin{tabular}{|c|c|c|c|c|c|c|}
\hline Karyotype & $\begin{array}{l}\mathrm{N}^{\circ} \text { of } \\
\text { cases }\end{array}$ & $\begin{array}{l}\text { Chromosomal } \\
\text { region }\end{array}$ & Rearrangement & Gene involved & MR syndrome & Reference \\
\hline \multirow{3}{*}{$\begin{array}{l}46, X Y, t(12 ; 20) \\
(q 24.31 ; q 11.2)\end{array}$} & \multirow[t]{3}{*}{1} & $12 q 24.31$-qter & \multirow{2}{*}{$\begin{array}{l}\text { Translocation/ } \\
\text { microdeletion }\end{array}$} & \multirow[t]{2}{*}{-} & \multirow[t]{2}{*}{-} & Callier et al. $2007 ;^{58}$ \\
\hline & & & & & & Bao et al. $2005^{59}$ \\
\hline & & $20 q 11.2$ & Duplication & $A S X L 1$ & - & Ávila et al. $2013^{60}$ \\
\hline $46, \mathrm{XY}, \operatorname{add}(15)$ & 1 & 15q26.1-26.2; & Deletion & $M E F 2 A, C H D 2$ & - & Davidson et al. 2008; 61 \\
\hline$(q 26)$ & & $15 q 26.2$-qter & & & & Capelli et al. $2012^{62}$ \\
\hline \multirow{5}{*}{$\begin{array}{l}46, X X, \operatorname{inv}(17) \\
(p 11.2 q 21)\end{array}$} & \multirow[t]{5}{*}{1} & $17 p 11.2$ & Deletion & TNFRSF1 & Smith-Magenis & Boudreau et al. 2009;63 \\
\hline & & & & $3 B, F A M 27 L$ & syndrome & Partida -Pérez et al. $2012^{64}$ \\
\hline & & 17q21.31; & Deletion; & CRHR1,MAPT & $17 q 21.31$ & Koolen et al. $2006 ; 65$ \\
\hline & & $17 q 21.32$ & duplication & & microdeletion & Grisart et al. 2009;66 \\
\hline & & & & & syndrome & Partida-Pérez et al. $2012^{64}$ \\
\hline \multirow{4}{*}{$\begin{array}{l}\text { 46,XY,inv(18) } \\
(\mathrm{p} 11.1 \mathrm{p} 11.32)\end{array}$} & \multirow[t]{4}{*}{1} & $18 \mathrm{p} 11.1$ & Deletion & - & \multirow{4}{*}{$\begin{array}{l}\text { Chromosome } 18 p \\
\text { deletion syndrome }\end{array}$} & Portnoi et al. $2007 ;{ }^{67}$ \\
\hline & & & & & & Wester et al. $2006^{68}$ \\
\hline & & 18p11.2; & Deletion, trisomy & - & & Portinoi et al. 2007; ${ }^{67}$ \\
\hline & & $18 p 11.32$ & & & & Moog et al. $1994^{69}$ \\
\hline $46, X X, r(22)$ & \multirow[t]{3}{*}{1} & $22 q 13 ; 22 q 13.3$ & Deletion; & SHANK3 & \multirow{3}{*}{$\begin{array}{l}22 q 13 \text { deletion } \\
\text { syndrome }\end{array}$} & Demirhan e Tunc, $2010 ;^{70}$ \\
\hline$(p 13 q 13)$ & & $22 q 13.31$ & translocation; & & & Koç et al. $2008^{71}$ \\
\hline$[17] / 46, X X[13]$ & & $22 q 13.1-q 13.2$ & duplication & & & \\
\hline
\end{tabular}

add: additional segment; del: deletion; der: derivative chromosome; ins: insertion; inv: inversion; r: ring chromosome; t: reciprocal translocation; p: short arm; q: long arm; ter: terminal.

opmental delay; or significant speech delay; or growth delay; or intellectual delay. ${ }^{20,21}$

\section{Conclusion}

Genetics is one of the areas of expertise that has most contributed to the elucidation of the causes of MR, with various possibilities for diagnosis. This study illustrates the contribution of G-banding karyotype analysis for investigation of the causes of $\mathrm{MR}$, since our results are in line with those reported in the literature. Structural chromosomal abnormalities were observed more frequently in this study. Knowing the critical regions on chromosomes is very important to correlate genotype and phenotype, and karyotype studies may help determine such regions. Therefore, although G-banding karyotype analysis may not be the most suitable test for syndromes related to mental retardation, since a large number of these syndromes are due to submicroscopic deletions and duplications, this technique proves to be useful for initial screening of affected individuals, and negative results should be evaluated using more accurate techniques such as aCGH and MLPA.

\section{Resumo}

Estudo retrospectivo de cariótipo em pacientes com retardo mental
Objetivo: descrever as alterações cromossômicas em pacientes com retardo mental (RM) pela análise do cariótipo com bandas $\mathrm{G}$.

Método: foi realizado um estudo retrospectivo dos resultados de cariótipo com bandas G de 369 pacientes em investigação de RM. A partir dos rearranjos estruturais encontrados, foram levantadas todas as regiões cromossômicas envolvidas nos pontos de quebra e elas foram comparadas com a literatura para RM e bancos de dados.

Resultados: foram identificados $338(91,6 \%)$ casos normais e $31(8,4 \%)$ com algum tipo de alteração cromossômica. Dentre os casos alterados, 21 pacientes $(67,8 \%)$ foram identificados com alterações cromossômicas estruturais, 9 (29\%) com alterações numéricas e 1 (3,2\%) com alteração numérica e estrutural.

Conclusão: as alterações cromossômicas estruturais foram aquelas observadas com maior frequência. O cariótipo com bandas $\mathrm{G}$ contribui para a investigação das causas de RM, mostrando que essa técnica pode ser útil como uma primeira triagem dos pacientes. No entanto, técnicas mais resolutivas como o array based comparative genomic bibridization (aCGH) e o multiplex ligation dependent probe amplification (MLPA) permitem detectar alterações submicroscópicas comumente associadas ao RM.

Palavras-chave: cariótipo, deficiência intelectual, aberrações cromossômicas. 


\section{References}

1. Dierssen M, Yann H, Estivill X. Aneuploidy: from a physiological mechanism of variance to Down syndrome. Physiol Rev. 2009; 89(3):887-920.

2. Speicher M, Antonarakis SE, Motulski AG. Vogel and Motulsky's human genetics: problems and approaches. 4.ed. Berlin: Springer Science \& Business Media, 2010.

3. Vasconcelos MM. Retardo mental. J Pediatr (Rio J.). 2004; 80(2):71-82

4. Stevenson RE: Splitting and lumping in the nosology of XLMR. Am J Med Genet. 2000; 97(3):174-82.

5. Shaffer LG, Slovak ML, Campbell LJ. ISCN - An International System for Human Cytogenetic Nomenclature. Basel: Karger AG, 2013.

6. Shevell M, Ashwal S, Donley D, Flint J, Gingold M, Hirtz D, et al. Practice parameter: evaluation of the child with global developmental delay: report of the Quality Standards Subcommittee of the American Academy of Neurology and The Practice Committee of the Child Neurology Society. Neurology. 2003; 60(3):367-80.

7. Shaffer LG, Bejjani BA. Using microarray-based molecular cytogenetic methods to identify chromosome abnormalities. Pediatr Ann. 2009; 38(8):440-7.

8. Jehee FS, Takamori JT, Medeiros PF, Pordeus AC, Latini FR, Bertola DR, et al. Using a combination of MLPA kits to detect chromosomal imbalances in patients with multiple congenital anomalies and mental retardation is a valuable choice for developing countries. Eur J Med Genet. 2011; 54(4):425-32.

9. Nussbaum RL, McInnes RR, Willard HF. Thompson \& Thompson genética médica. 6.ed. Rio de Janeiro: Guanabara Koogan, 2002. p.151-4.

10. Murphy MM, Mazzocco MM, Gerner G, Henry AE. Mathematics learning disability in girls with Turner syndrome or fragile $\mathrm{X}$ syndrome. Brain Cogn. 2006; 61(2):195-210

11. Ahuja AS, Thapar A, Owen MJ. Genetics of mental retardation. Indian J Med Sci. 2005; 59(9):407-17.

12. Rauch A, Hoyer J, Guth S, Zweier C, Kraus C, Becker C, et al. Diagnostic yield of various genetic approaches in patients with unexplained developmental delay or mental retardation. Am J Med Genet. 2006; 140(19):2063-74.

13. Anderson JS, Nielsen JA, Ferguson MA, Burback MC, Cox ET, Dai L, et al. Abnormal brain synchrony in Down syndrome. NeuroImage Clin. 2013; 2:703-15.

14. Liehr T, Karamysheva T, Merkas M, Brecevic L, Hamid AB, Ewers E, et al. Somatic mosaicism in cases with small supernumerary marker chromosomes. Curr Genomics. 2010; 11(6):432-9.

15. Liehr T, Weise A. Frequency of small supernumerary marker chromosomes in prenatal, newborn, developmentally retarded and infertility diagnostics. Int J Mol Med. 2007; 19(5):719-31

16. Mowat DR, Croaker GD, Cass DT, Kerr BA, Chaitow J, Adès LC, et al. Hirschsprung disease, microcephaly, mental retardation, and characteristic facial features: delineation of a new syndrome and identification of a locus at chromosome 2q22-q23. J Med Genet. 1998; 35(8):617-23.

17. Abu-Amero KK, Hellani A, Salih MA, Al Hussain A, al Obailan M, Zidan G, et al. Ophthalmologic abnormalities in a de novo terminal $6 \mathrm{q}$ deletion. Ophthalmic Genet. 2010; 31(1):1-11.

18. Mainardi PC, Perfumo C, Cali A, Coucourde G, Pastore G, Cavani S, et al. Clinical and molecular characterisation of 80 patients with $5 p$ deletion: genotype-phenotype correlation. J Med Genet. 2001; 38(3):151-8.

19. Harvard C, Malefant P, Koochek M, Creighton S, Mickelson EC, Holden JJ, et al. A variant Cri du Chat phenotype and autism spectrum disorder in a subject with de novo cryptic microdeletions involving 5 p 15.2 and 3 p24.3-25 detected using whole genomic array CGH. Clin Genet. 2005; 67(4):341-51.

20. Kaminsky EB, Kaul V, Paschall J, Church DM, Bunke B, Kunig D, et al. An evidence-based significance of CNVs in intellectual and developmental disabilities. Genet Med. 2011; 13(9):777-84

21. Miller DT, Adam MP, Aradhya S, Biesecker LG, Brothman AR, Carter NP, et al. Consensus statement: chromosomal microarray is a first-tier clinical diagnostic test for individuals with developmental disabilities or congenital anomalies. Am J Hum Genet. 2010; 86(5):749-64.

22. Lo IF, Cheung LY, Ng AY, Lam ST. Interstitial Dup(1p) with findings of Kabuki make-up syndrome. Am J Med Genet. 1998; 78(1):55-7.

23. Callier P, Faivre L, Thauvin-Robinet C, Marle N, Mosca AL, D'Athis P, e tal. Array-CGH in a series of 30 patients with mental retardation, dysmorphic features, and congenital malformations detected an interstitial 1p22.2-p31.1 deletion in a patient with features overlapping the Goldenhar syndrome. Am J Med Genet A. 2008; 146A(16):2109-15.

24. Ounap K, Bartsch O, Uibo O, Laidre P. Girl with combined cellular immunodeficiency, pancytopenia, malformations, deletion 11q23.3 --> qter, and trisomy 8q24.3 --> qter. Am J Med Genet. 2002; 108(4):322-6.

25. Weimer J, Cohen M, Wiedemann U, Heinrich U, Jonat W, Arnold N. Proof of partial imbalances $6 \mathrm{q}$ and $11 \mathrm{q}$ due to maternal complex balanced translocation analyzed by microdissection of multicolor labeled chromosomes (FISH-MD) in a patient with Dandy-Walker variant. Cytogenet Genome Res. 2006; 114(3-4):235-9.

26. Mach M, Windpassinger C, Wagner K, Kroisel PM, Petek E. Distal monosomy 16p13.3/distal trisomy 2p24.2-pter: molecular-cytogenetic characterisation and phenotype. Genet Couns. 2007; 18(1):9-16.

27. Talisetti A, Forrester SR, Gregory D, Johnson L, Schneider MC, Kimonis VE. Temtamy-like syndrome associated with translocation of $2 \mathrm{p} 24$ and $9 \mathrm{q} 32$ Clin Dysmorphol. 2003; 12(3):175-7.

28. Roggenbuck JA, Fink JM, Mendelsohn NJ. Unique case of trisomy 2p24.3pter with no associated monosomy. Am J Med Genet. 2001; 101(1):50-4

29. Balasubramaniam S, Keng WT, Ngu LH, Goossens MJ, Giurgea I. MowatWilson syndrome: the first two Malaysian cases. Singapore Med J. 2010; 51(3):e54-7.

30. Ballarati L, Recalcati MP, Bedeschi MF, Lalatta F, Valtorta C, Bellini M, et al. Cytogenetic, FISH and array-CGH characterization of a complex chromosomal rearrangement carried by a mentally and language impaired patient. Eur J Med Genet. 2009; 52(4):218-23.

31. Saunders CJ, Zhao W, Ardinger HH. Comprehensive ZEB2 gene analysis for Mowat-Wilson syndrome in a North American cohort: a suggested approach to molecular diagnostics. Am J Med Genet A. 2009; 149A(11):2527-31.

32. Héon E, Westall C, Carmi R, Elbedour K, Panton C, Mackeen L, et al. Ocular phenotypes of three genetic variants of Bardet-Biedl syndrome. Am J Med Genet A. 2005; 132A(3):283-7.

33. Ghadami M, Tomita HA, Najafi MT, Damavandi E, Farahvash MS Yamada K, et al. Bardet-Biedl syndrome type 3 in an Iranian family: clinical study and confirmation of disease localization. Am J Med Genet. 2000; 94(5):433-7.

34. Abreu-González M, García-Delgado C, Cervantes A, Aparicio-Onofre A, Guevara-Yáñez R, Sánchez-Urbina R, et al. Clinical, cytogenetic, and biochemical analysis of a family with a $\mathrm{t}(3 ; 13)(\mathrm{q} 26.2 ; \mathrm{p} 11.2)$ : further delineation of 3q duplication syndrome. Case Rep Genet. 2013; 2013:895259.

35. Faas BH, De Vries BB, Van Es-Van Gaal J, Merkx G, Draaisma JM, Smeets DF. A new case of dup (3q) syndrome due to a pure duplication of 3qter Clin Genet. 2002; 62(4):315-20

36. Gamerdinger U, Bosse K, Eggermann T, Kalscheuer V, Schwanitz G, Engels H. First report of a partial trisomy 3q12-q23 de novo--FISH breakpoint determination and phenotypic characterization. Eur J Med Genet. 2006; 49(3):225-34.

37. Okada N, Hasegawa T, Osawa M, Fukuyama Y. A case of de novo interstitial deletion 3q. J Med Genet. 1987; 24(5):305-8.

38. Amouroux C, Vincent M, Blanchet P, Puechberty J, Schneider A, Chaze AM, et al. Duplication 8q12: confirmation of a novel recognizable phenotype with duane retraction syndrome and developmental delay. Eur J Hum Genet. 2012; 20(5):580-3.

39. Verhoeven WM, Egger JI, Feenstra I, de Leeuw N. A de novo $3.57 \mathrm{Mb}$ microdeletion in $8 \mathrm{q} 12.3 \mathrm{q} 13.2$ in a patient with mild intellectual disability and epilepsy. Eur J Med Genet. 2012; 55(5):358-61.

40. Baialardo EM, Torrado Mdel V, Barreiro CZ, Gallego MS. Partial distal 5p trisomy resulting from paternal translocation $(5 ; 15)(\mathrm{p} 15.1 ; \mathrm{p} 13)$ in a boy with no mental retardation. Clin Dysmorphol. 2003; 12(4):257-9.

41. Webb GC, Voullaire LE, Rogers JG. Duplication of a small segment of 5p due to maternal recombination within a paracentric shift. Am J Med Genet. 1988; 30(4):875-81

42. Wu Q, Niebuhr E, Yang H, Hansen L. Determination of the 'critical region' for cat-like cry of Cri-du-chat syndrome and analysis of candidate genes by quantitative PCR. Eur J Hum Genet. 2005; 13(4):475-85.

43. Moreira LMA, Carvalho AFL, Borja ALVF, Pinto PSP, Silveira A, de Freitas LM, et al. Mosaic cri-du-chat syndrome in a girl with a mild phenotype. J Appl Genet. 2008; 49(4):415-20.

44. Laczmanska I, Stembalska A, Gil J, Czemarmazowicz H, Sasiadek M. Cri du chat syndrome determined by the 5 p15.3--> pter deletion-diagnostic problems. Eur J Med Genet. 2006; 49(1):87-92. 
45. Lukusa T, Willekens D, Lukusa N, De Cock F, Fryns JP. Terminal 6q25.3 deletion and abnormal behaviour. Genet Couns. 2001; 12(3):213-21.

46. Li P, Zhang HZ, Huff S, Nimmakayalu M, Qumsiyeh M, Yu J, et al. Karyotype-phenotype insights from 11q14.1-q23.2 interstitial deletions: FZD4 haploinsufficiency and exudative vitreoretinopathy in a patient with a complex chromosome rearrangement. Am J Med Genet A. 2006; 140(24):2721-9.

47. Sánchez LM, Labarta JD, De Negrotti TC, Migliorini AM. Complex translocation in a boy with trichorhinophalangeal syndrome. J Med Genet. 1985; 22(4):314-6

48. Debeer P, Devriendt K, De Smet L, deRavel T, Gonzalez-Meneses A, Grzeschik $\mathrm{KH}$, et al. The spectrum of hand and foot malformations in patients with Greig cephalopolysyndactyly. J Child Orthop. 2007; 1(2):1143-50.

49. Dunø M, Hove H, Kirchhoff M, Devriendt K, Schwartz M. Mapping genomic deletions down to the base: a quantitative copy number scanning approach used to characterise and clone the breakpoints of a recurrent $7 \mathrm{p} 14.2 \mathrm{p} 15.3$ deletion. Hum Genet. 2004; 115(6):459-67.

50. Wu Y, Ji T, Wang J, Xiao J, Wang H, Li J, et al. Submicroscopic subtelomeric aberrations in Chinese patients with unexplained developmental delay/ mental retardation. BMC Med Genet. 2010; 11:72.

51. Sanlaville D, Genevieve DD, Bernardin C, Amiel J, Baumann C, Blois MC, et al. Failure to detect an 8p22-8p23.1 duplication in patients with Kabuki (Niikawa-Kuroki) syndrome. Eur J Hum Genet. 2005; 13(5):690-93.

52. Zafra de la Rosa G, Venegas-Vega CA, Monroy N, Contreras-Bucio G, Friedrich $\mathrm{U}$, Houman M, et al. Trisomy 3q25.1-qter and monosomy 8p23.1-pter in a patient: cytogenetic and molecular analysis with delineation of the phenotype. Am J Med Genet A. 2005; 136(3):259-64.

53. Barbaro M, Balsamo A, Anderlid BM, Myhre AG, Gennari M, Nicoletti A, et al. Characterization of deletions at $9 p$ affecting the candidate regions for sex reversal and deletion 9p syndrome by MLPA. Eur J Hum Genet. 2009; 17(11):1439-47.

54. Yang Y, Wang C, Wang F, Zhu L, Liu H, He X. Novel chromosomal translocation $\mathrm{t}(11 ; 9)(\mathrm{p} 15 ; \mathrm{p} 23)$ involving deletion and duplication of $9 \mathrm{p}$ in a girl associated with autism and mental retardation. Gene. 2012; 502(2):154-8.

55. Lam AC, Lam ST, Lai KK, Tong TM, Chau TC. High rate of detection of subtelomeric aberration by using combined MLPA and subtelomeric FISH approach in patients with moderate to severe mental retardation. Clin Biochem. 2006; 39(3):196-202.

56. Kim JH, Lee WM, Ryoo NH, Ha JS, Jeon DS, Kim JR, et al. [A case of partial trisomy 15q25.3-qter]. Korean J Lab Med. 2009; 29(1):66-70.

57. Wagenstaller J, Spranger S, Lorenz-Depiereux B, Kazmierczak B, Nathrath $\mathrm{M}$, Wahl D, et al. Copy-number variations measured by single-nucleotidepolymorphism oligonucleotide arrays in patients with mental retardation. Am J Hum Genet. 2007; 81(4):768-79.

58. Callier P, Faivre L, Marle N, Thauvin-Robinet C, Mosca AL, Masurel-Paulet A, et al. Untreated growth hormone deficiency with extremely short stature, bone dysplasia, cleft lip-palate and severe mental retardation in a 26-year- old man with a de novo unbalanced translocation $\mathrm{t}(1 ; 12)(\mathrm{q} 24 ; \mathrm{q} 24)$. Eur J Med Genet. 2007; 50(6):455-64

59. Bao L, Schorry EK. A girl with partial trisomy $12 \mathrm{q} 24.31$ inherited from he father and a possible novel syndrome transmitted from her mother. Am J Med Genet A. 2005; 138(4):361-4.

60. Ávila M, Kirchhoff M, Marle N, Hode HD, Chouchane M, Thauvin-Robinet $\mathrm{C}$, et al. Delineation of a new chromosome 20q11.2 duplication syndrome including the ASXL1 gene. Am J Med Genet A. 2013; 161A(7):1594-8.

61. Davidsson J, Collin A, Björkhem G, Soller M. Array based characterization of a terminal deletion involving chromosome subband 15q26.2: an emerging syndrome associated with growth retardation, cardiac defects and developmental delay. BMC Med Genet. 2008; 9:2.

62. Capelli LP, Krepischi AC, Gurgel-Guianetti J, Mendes MF, Rodrigues T, Varela MC, et al. Deletion of the RMGA and CHD2 genes in a child with epilepsy and mental deficiency. Eur J Med Genet. 2012; 55(2):132-4.

63. Boudreau EA, Johnson KP, Jackman AR, Blancato J, Huizing M, Bendavid $\mathrm{C}$, et al. Review of disrupted sleep patterns in Smith-Magenis syndrome and normal melatonin secretion in a patient with an atypical interstitial $17 \mathrm{p} 11.2$ deletion. Am J Med Genet A. 2009; 149A(7):1382-91

64. Partida-Pérez M, Dominguez MG, Neira VA, Figuera LS, Rivera H. De novo $\operatorname{inv}(17)(\mathrm{p} 11.2 \mathrm{q} 21.3)$ in an intellectually disabled girl: appraisal of $21 \mathrm{inv}(17)$ constitutional instances. J Genet. 2012; 91(2):241-4.

65. Koolen DA, Vissers LE, Pfundt R, de Leeuw N, Knight SJ, Regan R, et al. A new chromosome 17q21.31 microdeletion syndrome associated with a common inversion polymorphism. Nat Genet. 2006; 38(9):999-1001.

66. Grisart B, Willat L, Destrée A, Fryns JP, Rack K, de Ravel T, et al. 17q21.3 microduplication patients are characterized by behavioural problems and poor social interaction. J Med Genet. 2009; 46(8):524-30.

67. Portnoï MF, Gruchy N, Marlin S, Finkel L, Denoyelle F, Dubourg C, et al. Midline defects in deletion 18p syndrome: clinical and molecular characterization of three patients. Clin Dysmorphol. 2007; 16(4):247-52.

68. Wester U, Bondenson ML, Edeby C, Annerén G. Clinical and molecular characterization of individuals with $18 p$ deletion: a genotype-phenotype correlation. Am J Med Genet A. 2006; 140(11):1164-71.

69. Moog U, Engelen JJ, de Die-Smulders CE, Albrechts JC, Loneus WH, Haagen $\mathrm{AA}$, et al. Partial trisomy of the short arm of chromosome 18 due to inversion duplication and direct duplication. Clin Genet. 1994; 46(6):423-9.

70. Dermirhan O, Tunç E. Phenotypic correlations in a patient with ring chromosome 22. Indian J Hum Genet. 2010; 16(2):97-9.

71. Koç A, Karaer K, Ergün MA, Yirmibeș-Karaoğuz M, Kan D, Cansu A, et al. A case with a ring chromosome 22. Turk J Pedriatr. 2008; 50(2):193-6.

72. MapViewer - National Center for Biotechnology Information. [cited 2014 Sep 3]. Available from: http://www.ncbi.nlm.nih.gov/projects/mapview/.

73. GenScript. [cited 2014 Sep 10]. Available from: http://www.genscript.com/ index.html/.

74. ClinVar - National Center for Biotechnology Information. [cited 2014 Sep 10]. Available from: http://www.ncbi.nlm.nih.gov/clinvar. 